\title{
Effect of extrusion-cooking conditions on the physical properties of Jerusalem artichoke straw
}

\author{
Karol Kupryaniuk@, Tomasz Oniszczuk@*, Maciej Combrzyński@*, Agnieszka Wójtowicz@*, \\ and Marcin Mitrus \\ Department of Thermal Technology and Food Process Engineering, University of Life Sciences in Lublin, Głęboka 31, \\ 20-612 Lublin, Poland
}

Received July 31, 2020; accepted September 24, 2020

\begin{abstract}
The paper presents the effect of extrusion-cooking conditions (moisture content and screw speed) on the physical properties of extruded Jerusalem artichoke straw. A single screw extruder was used for straw processing. Shredded Jerusalem artichoke straw moistened to 30,40 , and $50 \%$ was subjected to an extrusion-cooking process at various screw speeds (70, 90, and $110 \mathrm{rpm}$ ). Selected physical properties and pasting profile were tested. Significant differences were observed depending on the moisture content of the samples and the various screw speed on their physical properties. Notably, increased moisture content lowered the specific mechanical energy, increased processing efficiency, water solubility, peak viscosity and breakdown. The maximum efficiency and the highest breakdown was observed for the sample with $50 \%$ moisture content processed at an extruder screw speed of $90 \mathrm{rpm}$. The sample obtained at $30 \%$ moisture and at $90 \mathrm{rpm}$ was characterized by the lowest efficiency and hot paste viscosity, and the highest specific mechanical energy. The results showed that the extrusion-cooking process yielded desirable changes to the structure of the analysed lignocellulosic biomass.

Keywords: pretreatment, lignocellulosic biomass, physical properties, extrusion-cooking, Jerusalem artichoke straw
\end{abstract}

\section{INTRODUCTION}

In the last decade, rapid climate changes have been observed worldwide due to the increased emissions of greenhouse gasses produced, to a large extent, by conventional systems of power and heat generation (Pilarska et al., 2014). Most European governments recognize the need to change the directions of their current energy policies. There has been a notable turn towards renewable sources of ener-

*Corresponding authors e-mail: tomasz.oniszczuk@up.lublin.pl agnieszka.wojtowicz@up.lublin.pl maciej.combrzynski@up.lublin.pl gy as well as a growing interest in new, low-emission and more environmentally friendly technologies of energy production (Kozłowski et al., 2019a). Third generation peak biogas plants, which produce electrical energy in a specific time period when the requirement is urgent (e.g. between 6 a.m. and 9 p.m.), are a good example of such technologies. The location of the biogas plant as well as its nominal power is highly dependent on the available access to substrates. Typically, such facilities are located in the vicinity of large farms which provide a source of liquid and solid manure, as well as agri-food industry facilities, distilleries, or breweries, whose waste output can be fully utilized for the purposes of biogas production (Kozłowski et al., 2019b; Guerrieri et al., 2019). The use of such waste can often significantly reduce the costs of its utilization, additionally, the obtained digestate can be used as a natural fertilizer rich in nitrogen, phosphorus, and potassium. Agricultural biogas plants typically utilize corn, beet, and grass silage (Przybył et al., 2017). The price of corn silage has grown significantly in recent years (from approx. EUR 12 to EUR 30 for $\mathrm{Mg}^{-1}$ fresh matter (FM)) while governmental financial support has proven largely insufficient, hence investors are constantly on the lookout for potential new, more cost effective sources of substrates (Dach et al., 2014).

Agriculture continues to generate large quantities of unutilized organic waste in the form of so-called lignocellulosic biomass. This includes cereal, maize and rape straw, hay, as well as a wide range of other plants with consider-

(C) 2020 Institute of Agrophysics, Polish Academy of Sciences (c) (1) () $\Theta$ 
able energetic potential (Cieślik et al., 2016; Oniszczuk et al., 2016; Maj et al., 2019). The large quantities of biomass refuse coupled with the difficulty of finding ways to effectively utilize it, have encouraged the development of technologies capable of allowing its use in energy production. Biogas plants are a prime example of the effective utilization of organic waste by using it to produce heat and power. The process of methane fermentation conducted in such facilities is capable of handling waste materials that could potentially pose a threat to ecosystems (Wandera et $a l ., 2018)$. One of the plants recognized for its high energy potential is Jerusalem artichoke (Helianthus tuberosus), also known as sunchoke, which is characterized by significant production value and multi-directional processing usability. It is a fast-growing plant with high net calorific value, resistant to disease and pests, and with relatively low soil-quality requirements (Kowalczyk-Juśko, 2016).

However, the effective use of lignocellulosic biomass is problematic and difficult. In order to improve the speed and efficiency of the methane fermentation process, first lignocellulosic material has to be pretreated in order to disintegrate lignin and release cellulose and hemicelluloses (Kumar et al., 2009). Therefore, extensive research is currently being conducted with the aim of developing adequate methods for such pretreatment. As follows from the literature results, the inclusion of a pretreatment stage can improve the efficiency of biogas production by over $90 \%$ for raw materials such as grass, maize straw, or wood. Several distinct methods of lignocellulosic biomass pretreatment can be distinguished, including chemical, biological, mechanical, and extrusion-cooking (Robak and Balcerek, 2017; Kupryaniuk et al., 2020). It is impossible to identify the most effective method because the results are strongly dependent on the particular type of lignocellulosic biomass used in the given process. Each of the methods corresponds to specific technological processes which are employed at later stages. Indeed, production facilities often employ a combination of several methods to further enhance the efficiency of subsequent treatment. At the same time, although this approach improves the effectiveness of technological processes, it can also entail higher overall energy consumption and extend the time required for effective pretreatment. The decision to employ a given pretreatment method must be economically viable, which necessitates striking a viable compromise between the necessary expenditures and the ultimate profitability of production (Gizińska-Górna et al., 2016).

One such pretreatment method involves the process of extrusion-cooking, which is commonly used when processing food or feeds. The process is fast, simple, continuous, and highly efficient; it entails the thermal and mechanical treatment of raw plant materials (Witaszek et al., 2015). Under the influence of high temperatures (up to $200^{\circ} \mathrm{C}$ ), pressures (up to $20 \mathrm{MPa}$ ), and shearing forces, the physicochemical properties of the material placed in the extruder change, including protein denaturization, starch gelatinization, as well as the inactivation of enzymes, microorganisms, and many antinutrients. After leaving the extrusion die, the plasticized material undergoes the rapid expansion and evaporation of intracellular water, which yields a honeycomb-like structure and facilitates effective refinement (Kaur, 2015). The extrusion-cooking process utilizes single- and twin-screw extruders, with the time spent by the mass inside the machine being dependant on its specific design, the efficiency of the plasticizing system, and the rotational speed of the extruder screw - it can range from several seconds to a few minutes. The parameters of the process, including screw speed, extrusion temperature, screw configuration, and raw material moisture content, all have a significant impact on treatment efficiency and can affect the degree to which cellulose complexes are disintegrated. When lignocellulosic complexes are disintegrated, enzymes are provided with easier access to cellulose (Karunanithy et al., 2012).

The aim of the study was to investigate the effect of extrusion-cooking conditions (moisture content and screw speed) on the physical properties of Jerusalem artichoke extruded straw.

\section{MATERIAL AND METHODS}

The Jerusalem artichoke used in the study was harvested from the experimental field maintained by the University of Life Sciences in Lublin, from a 2019 cultivation. The straw was ground with a hammer shredder to reduce particle size to less than $5 \mathrm{~mm}$, and moistened to obtain three experimental moisture content levels (30, 40, and 50\%) by spraying with a suitable amount of water. Subsequently, the material was mixed using a laboratory drum mixer. Before processing, the material was stored in sealed bags for a period of $24 \mathrm{~h}$ to unify the migration of water. Afterwards, the samples were mixed again. The effective mixing duration was $10 \mathrm{~min}$.

The raw material moisture content was determined using the oven-drying method. Prepared weighing vessels containing finely ground $2 \mathrm{~g}$ samples (weighed with a $0.001 \mathrm{~g}$ accuracy $-1 / 3$ of the dish height) were placed inside the laboratory oven drier (POL-EKO, SLW 53 STD, Wodzisław Śląski, Poland) heated to $130^{\circ} \mathrm{C}$ and dried for $1 \mathrm{~h}$. After removal and cooling, the samples were weighed. The moisture content was calculated from the following equation:

$$
W=\frac{a-b}{a-c} 100,
$$

where: $W-$ is the material's moisture content (\%), $a-$ is the weight of the vessel containing the material prior to drying (g), $b$ - is the weight of the vessel containing the material after drying $(\mathrm{g}), c-$ is the mass of the empty vessel $(\mathrm{g})$. The measurements were conducted in triplicate. 
The study was performed using a single screw extrusion-cooker type TS-45 (Polish design) with the length to diameter ratio $L / D=12$ equipped with a plasticizing system with a modified recirculation section in the final part of the screw, and a forming die with an $8 \mathrm{~mm}$ hole diameter. Extrudates were produced at extruder screw speeds of 70 , 90 , and $110 \mathrm{rpm}$. The extrusion-cooking process temperature was set in the extruder sections at $80^{\circ} \mathrm{C}$ in the feeding zone, at $120^{\circ} \mathrm{C}$ in the transport zone and $150^{\circ} \mathrm{C}$ in the compression zone, respectively, and maintained at a constant level during processing. The processing temperature was measured with thermocouples installed along the barrel; the results were recorded. The rotational speed of the screw was monitored using a DM-2234B Laser electronic tachometer (Transfer Multisort Elektronik Ltd., Łódź, Poland). Ground straw without extrusion served as a control sample.

The processing efficiency $\left(Q, \mathrm{~kg} \mathrm{~h}^{-1}\right)$ was determined by measuring the mass of the extrudate obtained in a given time for all the raw materials and adopted process parameters. The measurements were conducted in triplicate for each study series with the mean results adopted as final. The extrusion-cooking process efficiency was determined as:

$$
Q=\frac{m}{t},
$$

where: $m$ - is the weight of extrudate obtained during the measurement $(\mathrm{kg}), t-$ is the measurement time $(\mathrm{h})$.

Energy consumption, expressed as specific mechanical energy ( $S M E, \mathrm{kWh} \mathrm{kg}^{-1}$ ) was calculated by taking into account the engine load, the extruder working parameters and the process efficiency of each test according to the formula (Combrzyński et al., 2020):

$$
S M E=\frac{n}{n_{m}} \frac{O}{100} \frac{P}{Q},
$$

where: $n$ - is screw rotation (rpm), $n_{m}$ - is the screw rating rotation (rpm), $O$ - is the engine load compared to the maximum (\%), $P$ - is rated power $(\mathrm{kW}), Q-$ is process efficiency $\left(\mathrm{kg} \mathrm{h}^{-1}\right)$. The final results were the means from the results obtained in triplicate.

The water absorption index (WAI) and the water solubility index (WSI) were used to evaluate the extrusioncooking intensity in accordance with the method described by Bouasla et al. (2017). For this purpose, $7 \mathrm{~mL}$ of distilled water was added to $0.7 \mathrm{~g}$ of the ground extruded sample. The sample was mixed, and then centrifuged for $10 \mathrm{~min}$ at $15000 \mathrm{rpm}$. The centrifuged samples were filtered, and the remains, after gel formation, were dried in an air oven at $130^{\circ} \mathrm{C}$ until completely dry. The WAI was calculated as the mass of gel formed per constant dry weight of the sample, and the WSI was calculated as the amount of residue dissolved in the supernatant after drying. All measurements were performed in triplicate.
Density measurements were performed according to Wójtowicz et al. (2017) by placing the analysed material into a measuring cylinder; the excess material was struck off and the cylinder filled with sample was weighed with a $0.01 \mathrm{~g}$ accuracy. Based on the result, the apparent density $\left(\rho_{u}, \mathrm{~kg} \mathrm{~m}^{-3}\right)$ was calculated as:

$$
\rho_{u}=\frac{m_{u}}{v},
$$

where: $m_{u}$ - is the weight of the sample $(\mathrm{kg}), v-$ is the dish volume $\left(\mathrm{m}^{3}\right)$. The measurement was conducted in triplicate.

The study of pasting properties was conducted to indirectly assess the changes taking place in the processed material during extrusion. The tests of raw and extruded straw were determined using a Brabender Micro ViscoAmylo-Graph (Brabender, Germany) following the method described by Bouasla et al. (2016) and Wójtowicz et al. (2017) with slight modification. $5 \mathrm{~g}$ of the ground extrudate was dispersed in $100 \mathrm{~mL}$ of distilled water. The pasting properties were evaluated at a constant speed $(250 \mathrm{rpm})$ and sensitivity $(235 \mathrm{cmg})$. Measurements were performed within the following profile: heating from 30 to $93^{\circ} \mathrm{C}$ with a temperature gradient of $7.5^{\circ} \mathrm{C} \mathrm{min}^{-1}$, holding at $93^{\circ} \mathrm{C}$ for $5 \mathrm{~min}$, cooling from 93 to $50^{\circ} \mathrm{C}$ with a temperature gradient of $7.5^{\circ} \mathrm{C} \mathrm{min}^{-1}$, holding at $50^{\circ} \mathrm{C}$ for $1 \mathrm{~min}$. Brabender Viscograph software (version 4.1.1) was used to determine the pasting properties. The measurements were conducted twice .

The results obtained were analysed using Statistica 13.3 software (StatSoft, Poland) to examine the effects of the initial moisture content and the screw rpm applied with ANOVA. Pearson's correlation coefficients were evaluated and an analysis of variance was conducted at a confidence level of $95 \%(\alpha=0.05)$; the significance of the observed differences was assessed using Duncan's range test.

\section{RESULTS AND DISCUSSION}

The rotational screw speed of the extruder and the initial moisture content of the material had a significant impact on the extrusion-cooking process itself and on the results of subsequent measurements. Table 1 presents the values of obtained selected physical properties of control and extruded Jerusalem artichoke straw samples in relation to the processing variables.

The material moisture content had a crucial influence on the processing efficiency results. The lowest value $\left(7.20 \mathrm{~kg} \mathrm{~h}^{-1}\right)$ was recorded for samples processed at $30 \%$ moisture content and an extruder screw speed of $90 \mathrm{rpm}$. The highest $\left(18.24 \mathrm{~kg} \mathrm{~h}^{-1}\right)$ - for samples extruded at $50 \%$ moisture and $90 \mathrm{rpm}$. Higher efficiency was reported by Ding et al. (2006) when extruding wheat-based snacks at moisture content levels of $14-22 \%$. In the case of the extruded wheat snacks, the processing efficiency reached was between 20 and $32 \mathrm{~kg} \mathrm{~h}^{-1}$. 
Table 1. Selected physical properties of the control and extruded Jerusalem artichoke straw relative to the processing variables

\begin{tabular}{|c|c|c|c|c|c|c|c|}
\hline Sample & $\begin{array}{c}\text { Moisture } \\
(\%)\end{array}$ & $\begin{array}{c}\text { Screw speed } \\
(\mathrm{rpm})\end{array}$ & $\begin{array}{c}Q \\
\left(\mathrm{~kg} \mathrm{~h}^{-1}\right)\end{array}$ & $\begin{array}{c}S M E \\
\left(\mathrm{kWh} \mathrm{kg}^{-1}\right)\end{array}$ & $\begin{array}{l}\text { WAI } \\
\left(\mathrm{g} \mathrm{g}^{-1}\right)\end{array}$ & $\begin{array}{l}\text { WSI } \\
(\%)\end{array}$ & $\begin{array}{c}\rho_{u} \\
\left(\mathrm{~kg} \mathrm{~m}^{-3}\right)\end{array}$ \\
\hline Control & & & & & $6.74^{\mathrm{c}}$ & $6.67^{\mathrm{c}}$ & $142.26^{\mathrm{ab}}$ \\
\hline M1R1 & & 70 & $10.92^{\mathrm{ab}}$ & $0.284^{\mathrm{a}}$ & $3.06^{\mathrm{a}}$ & $1.76^{\mathrm{a}}$ & $239.29^{c}$ \\
\hline M1R2 & 30 & 90 & $7.20^{\mathrm{a}}$ & $0.690^{\mathrm{c}}$ & $3.18^{\mathrm{a}}$ & $3.99^{\mathrm{ab}}$ & $172.58^{\mathrm{bc}}$ \\
\hline M1R3 & & 110 & $14.80^{\mathrm{b}}$ & $0.572^{\mathrm{bc}}$ & $3.43^{\mathrm{a}}$ & $2.61^{\mathrm{a}}$ & $128.42^{\mathrm{a}}$ \\
\hline M2R1 & & 70 & $10.80^{\mathrm{ab}}$ & $0.246^{\mathrm{a}}$ & $4.41^{\mathrm{ab}}$ & $3.08^{\mathrm{ab}}$ & $168.68^{\mathrm{bc}}$ \\
\hline M2R2 & 40 & 90 & $16.80^{\mathrm{bc}}$ & $0.267^{\mathrm{a}}$ & $3.54^{\mathrm{a}}$ & $4.03^{\mathrm{ab}}$ & $174.84^{\mathrm{bc}}$ \\
\hline M2R3 & & 110 & $14.04^{\mathrm{b}}$ & $0.447^{\mathrm{b}}$ & $4.68^{\mathrm{ab}}$ & $7.02^{c}$ & $156.93^{\mathrm{b}}$ \\
\hline M3R1 & & 70 & $10.92^{\mathrm{ab}}$ & $0.219^{\mathrm{a}}$ & $3.81^{\mathrm{a}}$ & $6.68^{c}$ & $129.39^{\mathrm{a}}$ \\
\hline M3R2 & 50 & 90 & $18.24^{\mathrm{c}}$ & $0.220^{\mathrm{a}}$ & $3.58^{\mathrm{a}}$ & $5.22^{\mathrm{bc}}$ & $150.54^{\mathrm{b}}$ \\
\hline M3R3 & & 110 & $17.04^{\mathrm{bc}}$ & $0.354^{\mathrm{ab}}$ & $4.05^{\mathrm{ab}}$ & $4.51^{\mathrm{b}}$ & $142.99^{\mathrm{ab}}$ \\
\hline
\end{tabular}

$\mathrm{M}$ - moisture, $\mathrm{R}$ - rotation, $Q$ - process efficiency, $S M E$ - specific mechanical energy, WAI - water absorption index, WSI - water solubility index, $\rho_{u}$ - apparent density, ${ }^{\mathrm{a}-\mathrm{c}}-$ means followed by similar letters in columns do not differ significantly at $\alpha=0.05$.

Table 2. Correlation matrix between processing variables and the physical and pasting properties of extruded Jerusalem artichoke straw

\begin{tabular}{|c|c|c|c|c|c|c|c|c|c|c|c|c|c|}
\hline & Moisture & $\begin{array}{l}\text { Screw } \\
\text { speed }\end{array}$ & $Q$ & $S M E$ & WAI & WSI & $\rho_{u}$ & IV & PV & HPV & $\mathrm{CPV}$ & FV & $\mathrm{BD}$ \\
\hline$Q$ & 0.521 & 0.520 & & & & & & & & & & & \\
\hline$S M E$ & $-0.644 *$ & 0.534 & -0.378 & & & & & & & & & & \\
\hline WAI & 0.176 & 0.435 & 0.305 & -0.020 & & & & & & & & & \\
\hline WSI & $0.658^{*}$ & 0.214 & 0.175 & -0.139 & 0.217 & & & & & & & & \\
\hline$\rho_{u}$ & -0.505 & -0.469 & -0.330 & -0.124 & -0.143 & -0.551 & & & & & & & \\
\hline IV & $0.843^{*}$ & 0.281 & $0.727 *$ & -0.540 & 0.531 & 0.587 & -0.419 & & & & & & \\
\hline PV & $0.868^{*}$ & 0.299 & $0.763 *$ & -0.521 & 0.480 & 0.545 & -0.405 & $0.976^{*}$ & & & & & \\
\hline HPV & $0.609 *$ & 0.500 & 0.511 & -0.131 & 0.344 & 0.295 & -0.311 & $0.637^{*}$ & $0.684 *$ & & & & \\
\hline $\mathrm{CPV}$ & $0.637^{*}$ & 0.264 & 0.314 & -0.260 & 0.532 & 0.303 & -0.298 & $0.683 *$ & $0.675^{*}$ & $0.890^{*}$ & & & \\
\hline FV & $0.620 *$ & 0.434 & 0.374 & -0.138 & 0.510 & 0.427 & -0.317 & $0.702 *$ & $0.698 *$ & $0.945^{*}$ & $0.961^{*}$ & & \\
\hline $\mathrm{BD}$ & $0.854^{*}$ & 0.232 & $0.754 *$ & -0.562 & 0.470 & 0.556 & -0.392 & $0.971^{*}$ & $0.987 *$ & 0.561 & 0.574 & 0.589 & \\
\hline SB & 0.302 & -0.313 & -0.213 & -0.367 & 0.532 & 0.061 & 0.025 & 0.331 & 0.246 & 0.279 & $0.677^{*}$ & 0.499 & 0.218 \\
\hline
\end{tabular}

$Q$ - process efficiency, $S M E$ - specific mechanical energy, WAI - water absorption index, WSI - water solubility index, $\rho_{u}-$ apparent density, IV - initial viscosity, PV - peak viscosity, HPV - hot paste viscosity, CPV - cold paste viscosity, FV - final viscosity, $\mathrm{BD}$ - breakdown, SB - setback, *significant effect at $\alpha \leq 0.05$.

The process energy consumption results presented in Table 1 were adversely affected to a significant extent by the moisture content (Table 2). It was observed that the SME decreased with higher moisture content, while increasing the screw speed increased energy consumption only in the case for samples moistened at 30 and $40 \%$. For samples moistened at $50 \%$, the difference was not significant. The highest $S M E$ value $\left(0.690 \mathrm{kWh} \mathrm{kg}^{-1}\right)$ was obtained for the sample processed at $30 \%$ moisture content and a screw speed of $90 \mathrm{rpm}$. The extrudates production process at $50 \%$ moisture and at $70 \mathrm{rpm}$ was characterized by the lowest values of $\operatorname{SME}\left(0.22 \mathrm{kWh} \mathrm{kg}^{-1}\right)$. As the degree of moisture content increases, the demand for energy decreases. In the case of raw material moistened up to $50 \%$, water behaved as a lubricant, the friction and shear forces during the extrusion process were lower, and this directly translates into lower energy consumption, regardless of the rotational speed of the extruder screw. Slight differences in energy demand in the case of samples with $50 \%$ initial moisture content may indicate that the extruder works as a heated screw conveyor, and the extrusion process takes place to a limited extent. 
The obtained results were higher compared to those reported by Hjorth et al. (2011) for extruded straw maize. It should also be mentioned that the study was conducted using a readapted device produced in the 1980s and equipped with a Shrage engine with an efficiency of 0.550.97 , depending on the nominal revolutions of the engine: 650-1950 rpm. The outdated engine construction significantly impacted the measurement results obtained. Modern engines installed in industrial extruders are characterized by significantly higher efficiency, which naturally has a bearing on the energy efficiency of the entire production process. The $S M E$ values obtained using laboratory equipment should be treated as rough estimates applicable to the TS-45 extruder, as such they merely illustrate the correlation between the type of raw materials used and the conditions of the extrusion-cooking process. It should be noted that a different energy consumption profile will be observed when using a new, more modern production unit (an industrial extruder) characterized by a considerably higher efficiency.

In terms of the water absorption index (WAI) the maximum value $\left(4.68 \mathrm{~g} \mathrm{~g}^{-1}\right)$, recorded for a sample extruded at $40 \%$ moisture content and with an extruder screw speed of $110 \mathrm{rpm}$, was significantly lower than that in the control untreated material $\left(6.74 \mathrm{~g} \mathrm{~g}^{-1}\right)$ (Table 1). The lowest WAI $\left(3.06 \mathrm{~g} \mathrm{~g}^{-1}\right)$ was obtained for the sample processed at $30 \%$ moisture and at the lowest screw speed. It was observed that in the case of a $30 \%$ moisture level, the WAI slightly increased with increasing screw speed. In the case of higher moisture level, there was a partial increase followed by a decrease in the WAI values observed but the differences between samples were insignificant. Wani and Kumar (2016) studied extrudates from oats and fenugreek beans processed at $17 \%$ moisture content, and reported the result of $5.86 \mathrm{~g} \mathrm{~g} \mathrm{~g}^{-1}$, which is higher than the result obtained for Jerusalem artichoke straw. A higher WAI value was only obtained for the untreated Jerusalem artichoke straw as the control sample $\left(6.74 \mathrm{~g} \mathrm{~g}^{-1}\right)$. No significant correlation was found between WAI and the processing variables.

The initial moisture content influenced the water solubility index (WSI) more intensively than the rotational screw speed of the extruder $(r=0.685)$. In the case of $30 \%$ moisture content, increasing the screw speed resulted in a partial increase, followed by a decrease in the WSI value but the differences were insignificant. At $40 \%$ moisture content, it was observed that WSI increased with growing rpm, while in the case of $50 \%$ moisture content, WSI decreased (Table 1). The highest value (7.02\%) was recorded for the sample extruded at $40 \%$ moisture content and at a screw speed of $110 \mathrm{rpm}$. This value was slightly but insignificantly higher than that obtained with the control untreated straw $(6.74 \%)$ which has a limited ability to absorb and hold water due to the high content of insoluble fibrous fractions. Extrusion-cooking in proper conditions may increase the water absorption ability of the sample. The lowest result
$(1.76 \%)$ was observed for the sample processed at $70 \mathrm{rpm}$ with $30 \%$ initial moisture because limited access to water at a low moisture content and low mechanical shearing using low rpm were insufficient to change the internal structure of the material significantly. Higher WSI values $(8.28 \%)$ were previously reported for the extrusion of corn grits with the $5 \%$ addition of propylene glycol (Ekielski et al., 2018).

Only in the case of samples extruded at $30 \%$ moisture and a screw speed of $110 \mathrm{rpm}$ (the lowest value of $128.42 \mathrm{~kg}$ $\left.\mathrm{m}^{-3}\right)$ and at $50 \%$ moisture and $70 \mathrm{rpm}\left(129.39 \mathrm{~kg} \mathrm{~m}^{-3}\right)$ were the recorded values of bulk density lower than those of the control, in all other cases the values recorded were higher but without significant differences (Table 1). The highest $\rho_{u}$ $\left(239.29 \mathrm{~kg} \mathrm{~m}^{-3}\right)$ was recorded for samples pretreated with an initial moisture content of $30 \%$ at the lowest rpm due to the incomplete transformation of components. Compared to corn porridge with the addition of linseed pomace (Makowska, 2013), it was observed that the densities of the control sample without an additive and extrudates with $25 \%$ additive would achieve twice the value recorded for extruded Jerusalem artichoke straw, which may be connected with the structure of straw which is different from that of the flour components.

The pasting characteristics of extrudates may serve as a measure of component processing intensity relative to the process variables employed in extrusion-cooking (Deepa and Hebbar, 2017; Hagenimana et al., 2006; Koh and Singh, 2009). The pasting profiles of the selected samples of extruded Jerusalem artichoke straw are presented in Figs 1 and 2, relative to the initial moisture level and screw rpm used in the experiment.

For the control (non-extruded) sample, an initial increase in viscosity was observed while the suspension was heated to $93^{\circ} \mathrm{C}$. This may provide evidence of the enhanced absorption of water by the unprocessed straw and the presence of starch undergoing gelatinization during heating. While the sample was maintained at a temperature of $93^{\circ} \mathrm{C}$, the suspension viscosity was observed to gradually decrease, which may suggest a partial disintegration of lignocellulose during heating and, possible dissolution of the substrates (including sugars) in water. As the suspension temperature decreased, the viscosity increased once more, which may suggest the formation of a viscous structure by the lignocellulosic material after cooling.

In the case of the extruded straw, we observed a considerable reduction or complete absence of an increase in viscosity during the initial heating stage of the suspension. This suggests that significant physicochemical changes have occurred during the extrusion-cooking of the straw, which ultimately led to the breakdown of a considerable part of the lignocellulose, possibly down to simple sugars which do not undergo gelatinization. A similar behaviour was observed for extruded starch (Mitrus et al., 2017) and extruded bean (de la Rosa-Millan et al., 2019). At the heating up stage and maintenance of the temperature at $93^{\circ} \mathrm{C}$, 


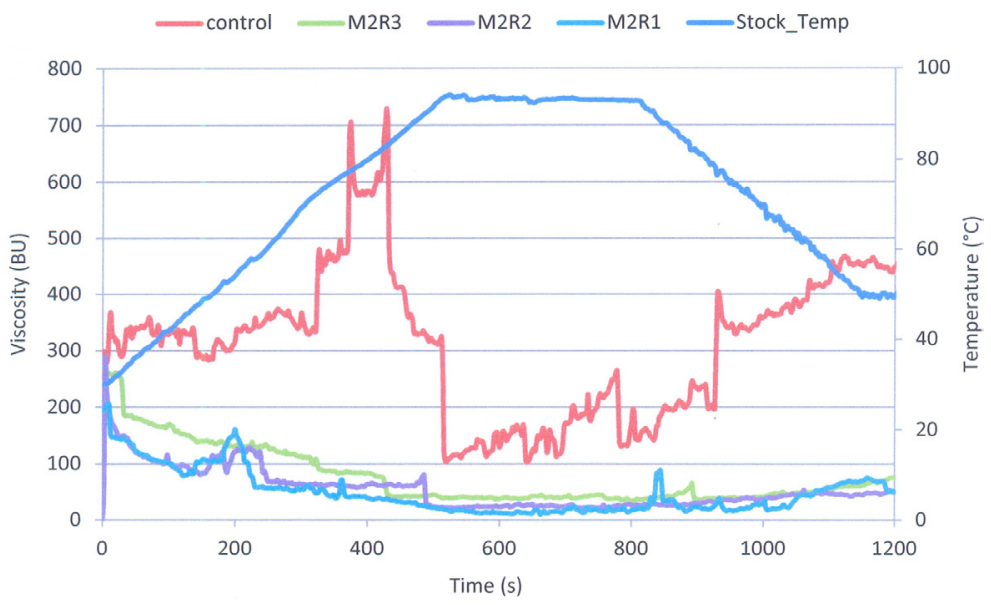

Fig. 1. Pasting profile of the control and extruded Jerusalem artichoke straw moistened at $40 \%$ and processed at various screw speeds.

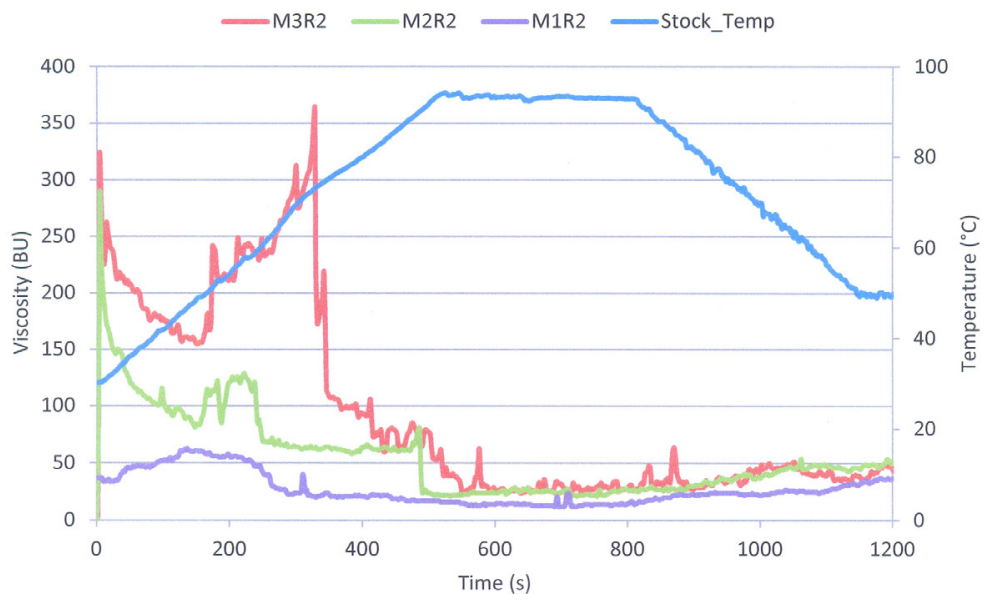

Fig. 2. Pasting profile of extruded Jerusalem artichoke straw processed at $90 \mathrm{rpm}$ at various moisture levels.

Table 3. Pasting characteristics of the control and extruded Jerusalem artichoke straw relative to the processing variables

\begin{tabular}{|c|c|c|c|c|c|c|c|c|c|}
\hline Sample & $\begin{array}{c}\text { Moisture } \\
(\%)\end{array}$ & $\begin{array}{l}\text { Screw } \\
\text { speed } \\
(\mathrm{rpm})\end{array}$ & $\begin{array}{c}\text { IV } \\
(\mathrm{BU})\end{array}$ & $\begin{array}{c}\mathrm{PV} \\
(\mathrm{BU})\end{array}$ & $\begin{array}{l}\mathrm{HPV} \\
(\mathrm{BU})\end{array}$ & $\begin{array}{l}\text { CPV } \\
(\mathrm{BU})\end{array}$ & $\begin{array}{c}\mathrm{FV} \\
(\mathrm{BU})\end{array}$ & $\begin{array}{c}\mathrm{BD} \\
(\mathrm{BU})\end{array}$ & $\begin{array}{c}\mathrm{SB} \\
(\mathrm{BU})\end{array}$ \\
\hline Control & \multirow{4}{*}{30} & & $337^{\mathrm{c}}$ & $710^{c}$ & $187^{\mathrm{c}}$ & $442^{\mathrm{c}}$ & $443^{c}$ & $523^{c}$ & $256^{\mathrm{c}}$ \\
\hline M1R1 & & 70 & $40^{\mathrm{a}}$ & $48^{\mathrm{a}}$ & $16^{\mathrm{a}}$ & $25^{\mathrm{a}}$ & $24^{\mathrm{a}}$ & $32^{\mathrm{a}}$ & $18^{\mathrm{ab}}$ \\
\hline M1R2 & & 90 & $45^{\mathrm{a}}$ & $61^{\mathrm{a}}$ & $16^{\mathrm{a}}$ & $30^{\mathrm{a}}$ & $37^{\mathrm{ab}}$ & $46^{\mathrm{a}}$ & $15^{\mathrm{ab}}$ \\
\hline M1R3 & & 110 & $77^{\mathrm{a}}$ & $77^{\mathrm{a}}$ & $16^{\mathrm{a}}$ & $21^{\mathrm{a}}$ & $21^{\mathrm{a}}$ & $61^{\mathrm{a}}$ & $6^{\mathrm{a}}$ \\
\hline M2R1 & \multirow{3}{*}{40} & 70 & $198^{\mathrm{ab}}$ & $201^{\mathrm{ab}}$ & $17^{\mathrm{a}}$ & $68^{\mathrm{b}}$ & $50^{\mathrm{ab}}$ & $184^{\mathrm{ab}}$ & $51^{\mathrm{b}}$ \\
\hline M2R2 & & 90 & $276^{\mathrm{bc}}$ & $276^{\mathrm{b}}$ & $25^{\mathrm{ab}}$ & $45^{\mathrm{ab}}$ & $50^{\mathrm{ab}}$ & $251^{\mathrm{b}}$ & $19^{\mathrm{ab}}$ \\
\hline M2R3 & & 110 & $254^{\mathrm{b}}$ & $255^{\mathrm{b}}$ & $34^{\mathrm{b}}$ & $59^{\mathrm{ab}}$ & $74^{\mathrm{b}}$ & $221^{\mathrm{b}}$ & $25^{\mathrm{ab}}$ \\
\hline M3R1 & \multirow{3}{*}{50} & 70 & $195^{\mathrm{ab}}$ & $195^{\mathrm{ab}}$ & $26^{\mathrm{ab}}$ & $52^{\mathrm{ab}}$ & $52^{\mathrm{ab}}$ & $169^{\mathrm{ab}}$ & $26^{\mathrm{ab}}$ \\
\hline M3R2 & & 90 & $274^{\mathrm{bc}}$ & $353^{\mathrm{bc}}$ & $30^{\mathrm{b}}$ & $38^{\mathrm{a}}$ & $41^{\mathrm{ab}}$ & $323^{\mathrm{bc}}$ & $8^{\mathrm{a}}$ \\
\hline M3R3 & & 110 & $307^{\mathrm{bc}}$ & $361^{\mathrm{bc}}$ & $87^{\mathrm{bc}}$ & $121^{\mathrm{bc}}$ & $129^{\mathrm{bc}}$ & $273^{\mathrm{b}}$ & $34^{\mathrm{b}}$ \\
\hline
\end{tabular}

$\mathrm{M}$ - moisture, $\mathrm{R}$ - rotation, IV - initial viscosity, PV - peak viscosity, HPV - hot paste viscosity, CPV - cold paste viscosity, FV - final viscosity, BD - breakdown, $\mathrm{SB}$ - setback, ${ }^{\mathrm{a}-\mathrm{c}}$ - means followed by similar letters in columns do not differ significantly at $\alpha=0.05$. 
a decrease in the suspension's viscosity was observed, which may indicate that the components obtained from lignocellulose disintegration were dissolved in water (Figs 1 and 2). While cooling the suspension, we observed only a slight increase in viscosity, which provides evidence of the considerably reduced extent of lignocellulosic structure reformation. In general, it may be concluded that the use of higher extruder screw speeds resulted in less intensive changes to the extruded straw, as shown by the higher viscosities of the obtained suspensions. As the screw speed increased, the straw spent less overall time inside the extruder, which meant a shorter processing time and less intensive physicochemical changes.

Various straw moisture contents prior to extrusion as well as variable screw speeds positively correlated with all the tested pasting characteristics, with the exception of SB, but an insignificant correlation between the screw speed and pasting characteristics has been noted (Table 2). This suggests that the moisture level is more responsible for the intensity of the extrusion-cooking processing of straw, and influences the extensive physicochemical changes to the extruded material. As a result, such samples produced at a low screw speed and with low initial moisture material whose water suspensions were tested, are characterized by a lower viscosity, this is probably due to the insufficient pretreatment of the extruded straw.

The maximum viscosity recorded during the heating stage (PV) was $710 \mathrm{BU}$ for raw straw and varied from 48 to $361 \mathrm{BU}$ for extruded samples, as shown in Table 3. The highest value was recorded for the control sample, while the remaining results were half of the value of the control sample or lower. A high degree of correlation (Table 3) was found between PV and IV $(r=0.976)$.

Both, IV and PV were significantly correlated with the initial moisture content of Jerusalem artichoke straw ( $\mathrm{r}=$ 0.843 and 0.868 , respectively). HPV was positively and highly correlated with the CPV and FV values $(r=0.890$ and 0.945 , respectively). The cold paste viscosity (CPV) varied from 21 to $121 \mathrm{BU}$ for extruded straw, but the highest CPV value was recorded for the control of the untreated sample - nearly four times the results obtained for extruded samples. The lowest values of FV (21-30 BU) were recorded for the extrudates processed at $30 \%$ moisture whereas for untreated material FV was $443 \mathrm{BU}$ - over 10 times more than those of the extruded samples. The breakdown (BD) varied from 32 to $323 \mathrm{BU}$. The lowest values were recorded for the extrudate processed at $30 \%$ moisture and $70 \mathrm{rpm}$. The pasting properties which were evidently influenced by the moisture level included: CPV, FV, and BD. The changes in extruder screw speed had a clear impact on HPV (hot paste viscosity) only at 40 and $50 \%$ moisture levels, whereas at $30 \%$ moisture content the obtained results remained roughly unchanged. The values of SB reached 6-34 BU and the results were not observably affected by either moisture level or extruder screw speed with the highest value being observed for the untreated sample (256 BU). The extruder screw speed had no clear effect on the values obtained from the measurements. Significant correlations between Q and the variable pasting properties were observed, including IV $(r=0.727), P V(r=0.763)$, and $\mathrm{BD}(r=0.754)$.

\section{CONCLUSIONS}

1. Maximum processing efficiency $\left(18.24 \mathrm{~kg} \mathrm{~h}^{-1}\right)$ was observed for the sample processed at $50 \%$ moisture level and an extruder screw speed of $90 \mathrm{rpm}$.

2. The extrudates production process at $50 \%$ moisture and at $70 \mathrm{rpm}$ was characterized by the lowest values of specific mechanical energy $\left(0.22 \mathrm{kWh} \mathrm{kg}^{-1}\right)$.

3. The sample processed at $30 \%$ moisture and $90 \mathrm{rpm}$ was characterized by the lowest efficiency $\left(7.20 \mathrm{~kg} \mathrm{~h}^{-1}\right)$ and highest specific mechanical energy $\left(0.690 \mathrm{kWh} \mathrm{kg}^{-1}\right)$.

4. The material processed at $40 \%$ moisture content and an extruded screw speed of $110 \mathrm{rpm}$ was characterized by the highest WSI (7.02\%), while in the case of WAI $\left(4.68 \mathrm{~g} \mathrm{~g}^{-1}\right)$, only the control sample yielded a higher WAI result $\left(6.74 \mathrm{~g} \mathrm{~g} \mathrm{~g}^{-1}\right)$.

5. The sample extruded at a $30 \%$ moisture level and a screw speed of $70 \mathrm{rpm}$ was characterized by the lowest WSI $(1.76 \%)$ and highest density $\left(239.29 \mathrm{~kg} \mathrm{~m}^{-3}\right)$.

6 . In terms of the pasting properties of extruded straw, the control sample yielded significantly higher results relative to those obtained for the extruded material. The results were significantly influenced by the moisture level.

7. The optimum extrusion-cooking conditions for the pretreatment of Jerusalem artichoke straw were a moisture content that reached $40 \%$ and a screw speed that was set to $110 \mathrm{rpm}$.

Conflict of interest: The Authors do not declare any conflict of interest.

\section{REFERENCES}

Bouasla A., Wójtowicz A., and Zidoune M.N., 2017. Glutenfree precooked rice pasta enriched with legumes flours: physical properties, texture, sensory attributes and microstructure. LWT-Food Sci. Technol., 75, 569-577. https:// doi.org/10.1016/j.lwt.2016.10.005

Bouasla A., Wójtowicz A., Zidoune M.N., Olech M., Nowak R., Mitrus M., and Oniszczuk A., 2016. Gluten-free precooked rice-yellow pea pasta: effect of extrusion-cooking conditions on phenolic acids composition, selected properties and microstructure. J. Food Sci., 81, C1070-C1079. https://doi.org/10.1111/1750-3841.13287

Cieślik M., Dach J., Lewicki A., Smurzyńska A., Janczak D., Pawlicka-Kaczorowska J., Boniecki P., Cyplik P., Czekała W., and Jóźwiakowski K., 2016. Methane fermentation of the maize straw silage under meso- and thermophilic conditions. Energy, 115(2), 1495-1502. https://doi.org/10.12911/22998993/83563

Combrzyński M., Matwijezuk A., Wójtowicz A., Oniszczuk T., Karcz D., Szponar J., Niemczynowicz A., Bober D., 
Mitrus M., Kupryaniuk K., Stasiak M., Dobrzański B., and Oniszczuk A., 2020. Potato starch utilization in ecological loose-fill packaging materials-sustainability and characterization. Materials, 13, 1390. https://doi.org/10.3390/ma13061390

Dach J., Boniecki P., Przybył J., Janczak D., Lewicki A., Czekała W., Witaszek K., Rodriguez Carmona P.C., and Cieślik M., 2014. Energetic efficiency analysis of the agricultural biogas plant in $250 \mathrm{~kW}_{\mathrm{e}}$ experimental installation. Energy, 69, 34-38. https://doi.org/10.1016/j.energy.2014.02.013

Deepa C. and Hebbar H.U., 2017. Influence of micronization on physicochemical properties of maize grains. J. Food Process. Preserv., 41, Art. No. 13195. https://doi.org/10.1111/jfpp.13195

De la Rosa-Millan J., Heredia-Olea E., Perez-Carrilo E., Guajardo-Flores D., and Serna-Saldivar S.R.O., 2019. Effect of decortication, germination and extrusion on physicochemical and in vitro protein and starch digestion characteristics of black beans (Phaseolus vulgaris L.). LWT-Food Sci. Technol., 102, 330-337. https://doi. org/10.1016/j.lwt.2018.12.039

Ding Q.B., Ainswirth P., Plinkett A., Tucker G., and Marson H., 2006. The effect of extrusion conditions on the functional and physical properties of wheat-based expanded snacks. J. Food Eng., 73(2), 142-148. https://doi.org/10.1016/j.jfoodeng.2005.01.013

Ekielski A., Żeleziński T., Siwek A., Sharma V., and Mishra P.K., 2018. Formulation and characterization of corn grits-propylene glycol extrudates. Materials Today: Proc., 21, 1772-1780. https://doi.org/10.1016/j.matpr.2020.01.230

Gizińska-Górna M., Czekala W., Jóźwiakowski K., Lewicki A., Dach J., Marzec M., Pytka A., Janczak D., KowalczykJuśko A., and Listosz A., 2016. The possibility of using plants from hybrid constructed wetland waste water treatment plant for energy purposes. Ecol. Eng., 95. 534-541. https://doi.org/10.1016/j.ecoleng.2016.06.055

Guerrieri A.S., Anifantis A.S., Santoro F., and Pascuzzi S., 2019. Study of a large square baler with innovative technological systems that optimize the baling effectiveness. Agriculture, 9(5), 86. https://doi.org/10.3390/agriculture 9050086

Hagenimana A., Ding X., and Fang T., 2006. Evaluation of rice flour modified by extrusion cooking. J. Cereal Sci., 43, 38-46. https://doi.org/10.1016 / j.jcs.2005.09.003

Hjorth M., Gränitz K., Adamsen A.P.S., and Møller H.B., 2011. Extrusion as a pretreatment to increase biogas production. Bioresour. Technol., 102, 4989-4994. https://doi.org/10.1016/j.biortech.2010.11.128

Karunanithy C., Muthukumarappan K., and Gibbons W.R., 2012. Extrusion pretreatment of pine wood chips. Appl. Biochem. Biotechnol., 167, 81-99. https://doi.org/10.1007/ s12010-012-9662-3

Kaur J., 2015. Effect of extrusion pre-treatment on physical properties and sugar recovery of cold press and solvent extracted canola, camelina and carinata meal. Master Thesis, South Dakota State University, https://openprairie.sdstate.edu/ etd/1829
Koh B.K. and Singh V., 2009. Cooking behavior of rice and black gram in the preparation of Idli, a traditional fermented product of Indian origin, by viscography. J. Texture Stud., 40, 36-50.

https://doi.org/10.1111/j.1745-4603.2008.00168.x

Kowalczyk-Juśko A., 2019. Chemical composition and energetic characteristics of Miscanthus sacchariflorus biomass as used for generation of energy. Przem. Chem., 95/11. https:// doi.org/10.15199/62.2016.11.37

Kozłowski K., Lewicki A., Czekała W., Wójtowicz A., Kupryaniuk K., and Dróżdż D., 2019a. Extrusion pretreatment of maize straw - case study for a Polish biogas plants. Int. Agrophys., 33, 527-535, https://doi: 10.31545/ intagr/113548

Kozłowski K., Pietrzykowski M., Czekała W., Dach J., Kowalczyk-Juśko A., and Jóźwiakowski K., 2019 b. Energetic and economic analysis of biogas plant with using the dairy industry waste. Energy, 183, 1023-1031. https:// doi.org/10.1016/j.energy.2019.06.179

Kumar A.K. and Sharma S., 2017. Recent updates on different methods of pretreatment of lignocellulosic feedstocks: a review. Bioresour. Bioprocess, 4, 7. https://doi.org/10.1186/s40643-017-0137-9

Kumar P., Barrett D.M., Delwiche M.J., and Stroeve P., 2009. Methods for pretreatment of lignocellulosic biomass for efficient hydrolysis and biofuel production. Ind. Eng. Chem. Res., 48, 8, 3713-3729. https://doi.org/10.1021/ ie $801542 \mathrm{~g}$

Kupryaniuk K., Oniszczuk T., Combrzyński M., Czekała W., and Matwijczuk A., 2020. The influence of corn straw extrusion pretreatment parameters on methane fermentation performance. Materials, 13(13), 3003. https://doi. org/10.3390/ma13133003

Maj G., Szyszlak-Bargłowicz J., Zając G., Słowik T., Krzaczek P., and Piekarski W., 2019. Energy and emission characteristics of biowaste from the corn grain drying process. Energies, 12(22), 4383. https://doi.org/10.3390/en12224383

Makowska M., 2013. Effect of flaxseed by-product addition on quality of extruded snacks (in Polish). Aparatura Badawcza i Dydaktyczna, 18(4), 309-316.

Mitrus M., Wójtowicz A., Oniszczuk T., Gondek E., and Combrzyński M., 2017. Effect of processing conditions on microstructure and pasting properties of extrusion-cooked starches. Int. J. Food Eng., 13(6), 20160287. https://doi. org/10.1515/ijfe-2016-0287

Oniszczuk T., Wójtowicz A., Mościcki L., Mitrus M., Kupryaniuk K., Kusz A., and Bartnik G., 2016. Effect of natural fibres on the mechanical properties of thermoplastic starch. Int. Agrophys., 30, 211-218. https://doi.org/10.1515/intag-2015-0080

Pilarska A., Pilarski K., and Ryniecki A., 2014. The use of methane fermentation in the development of selected waste products of food industry (in Polish). Nauki Inżynierskie i Technologie, 4(15), 100-111. https://doi.org/10.15611/ nit.2014.4.08

Przybył J., Dach J., Wojcieszak D., Mazurkiewicz J., and Zaborowicz M., 2017. The possibility of maize straw application as a substrate for biogas plants. Proc. 9th Int. Scientific Symp. Farm Machinery and Process Management in Sustainable Agriculture, 318-323. https://doi.org/10.24326/fmpmsa.2017.57 
Robak K. and Balcerek M., 2017. Role of lignocellulosic biomass pretreatment in the production of bioethanol II generation (in Polish). Acta Agroph., 24(2), 301-318.

Rodiahwati W. and Sriariyanun M., 2016. Lignocellulosic biomass to biofuel production: integration of chemical and extrusion (screw press) pretreatment. KMUTNB Int. J. Appl. Sci. Technol., 9, 289-298. https://doi.org/10.14416/j. ijast.2016.11.001

Wandera S.M., Qiao W., Algapani D.E., Bi S., Yin D., and Qi X., 2018. Searching for possibilities to improve the performance of full scale agricultural biogas plants. Renew Energy, 116, 720-727.

https://doi.org/10.1016/j.renene.2017.09.087
Wani S.A. and Kumar P., 2016. Development and parameter optimalization of health promising extrudates based on fenugreek oat and pea. Food Biosci., 14, 34-40. https://doi. org/10.1016/j.fbio.2016.02.002

Witaszek K., Pilarska A., and Pilarski K., 2015. Selected methods of vegetable raw material pre-treatment used in biogas production (in Polish). Ekonomia i Środowisko, 2(53), 130-144.

Wójtowicz A., Oniszczuk A., Oniszczuk T., Kocira S., Wojtunik K., Mitrus M., Kocira A., Widelski J., and SkalickaWoźniak K., 2017. Application of Moldavian dragonhead (Dracocephalum moldavica L.) leaves addition as a functional component of nutritionally valuable corn snacks. J. Food Sci. Technol., 54(10), 3218-3229. https://doi.org/10.1007/s13197-017-2765-7 